Review

\title{
Biomarkers of Immunotoxicity for Environmental and Public Health Research
}

\section{Paurene Duramad ${ }^{1}$ and Nina T. Holland ${ }^{2, *}$}

1 Genentech, Inc., 1 DNA Way MS \#59, South San Francisco, CA 94080, USA;

E-Mail: paurened@gene.com

2 School of Public Health, University of California, Berkeley, 733 University Hall, Berkeley, CA 94720-7360, USA

* Author to whom correspondence should be addressed; E-Mail: ninah@berkeley.edu.

Received: 18 February 2011; in revised form: 26 March 2011 / Accepted: 25 April 2011 / Published: 6 May 2011

\begin{abstract}
The immune response plays an important role in the pathophysiology of numerous diseases including asthma, autoimmunity and cancer. Application of biomarkers of immunotoxicity in epidemiology studies and human clinical trials can improve our understanding of the mechanisms that underlie the associations between environmental exposures and development of these immune-mediated diseases. Immunological biomarkers currently used in environmental health studies include detection of key components of innate and adaptive immunity (e.g., complement, immunoglobulin and cell subsets) as well as functional responses and activation of key immune cells. The use of high-throughput assays, including flow cytometry, Luminex, and Multi-spot cytokine detection methods can further provide quantitative analysis of immune effects. Due to the complexity and redundancy of the immune response, an integrated assessment of several components of the immune responses is needed. The rapidly expanding field of immunoinformatics will also aid in the synthesis of the vast amount of data being generated. This review discusses and provides examples of how the identification and development of immunological biomarkers for use in studies of environmental exposures and immune-mediated disorders can be achieved.
\end{abstract}

Keywords: asthma; COPD; biomarker validation; immunoinformatics; Luminex; immunome; immunotoxicity 


\section{Introduction}

The field of immunotoxicology has rapidly expanded and the main drivers for this development include recognition that environmental chemicals can alter immune response and function, increase in immune-mediated diseases (asthma, allergies, type 1 diabetes, rheumatoid arthritis, etc.) [1-4], and recognition that the immune system plays an important role in the pathophysiology of other disease states such as cancer [1] and atherosclerosis [2-4]. A pro-inflammatory immune response contributes to tissue and organ damage and is a common factor in many auto-immune diseases (e.g., Type 1 diabetes, rheumatoid arthritis, systemic lupus erythermatosus) and other disorders (e.g., promotion of atherosclerotic plaques in cardiovascular disease). Conversely, the lack of an appropriate inflammatory immune response contributes to lowered immune surveillance and the progression of tumors and cancers. A thorough understanding of the role of the immune response in the pathophysiology of these diseases is important to identify efficacious therapies and effective interventions. Further, the prevention of these diseases can be aided when specific and sensitive biomarkers, particularly ones that precede clinical onset of these diseases, are identified.

A biomarker is defined as "a characteristic that is evaluated as an indicator of normal biological or pathogenic processes, or a pharmacological response to a therapeutic intervention [5,6]." Biomarkers have been used for many years in toxicology and risk assessment and are often classified in terms of biomarkers of exposure, effect, and susceptibility [7]. However, categories based on intended roles and applications (e.g., disease, efficacy, mechanism, pharmacodynamic, and target) provide a useful classification system (see Baker et al. 2005 [8]). Disease-related biomarkers are mostly used for monitoring disease causality, progression, and susceptibility, and, to some extent, to identify strategies for patient stratification [9]. Both regulatory agencies and industry are keen to identify biomarkers that will aid in the early detection of toxicities [6,7,10,11].

\section{Key Considerations for Developing Biomarkers of Immunotoxicity}

Development of disease biomarkers broadly involves the three stages of identification, validation, and application (see Figure 1) and key elements of the process include (1) identifying biomarkers that can establish relevance (i.e., related to the disease of exposure of interest), (2) strong, mechanistic molecular or biochemical basis in the pathophysiology of a disease, (3) sensitivity and specificity to treatment or exposure, (4) reliability (reproducibility, accuracy, precision, robustness), (5) practicality (level of assay invasiveness), and (6) simplicity in use and application [12,13]. Rarely does one biomarker meet all six requirements, however early consideration of these parameters in properly-designed and statistically powered studies can improve the final predictive value of biomarkers [14].

Since the immune system is composed of multiple organs (e.g., bone marrow, thymus, spleen and lymph nodes) and an appropriate immune response involves the interaction of multiple cell types (e.g., dendritic, B, and T-helper cells) and pleiotropic components (e.g., immunoglobulin and cytokines) it is a challenge to identify a key parameter to develop as a biomarker. Immunotoxic effects are commonly categorized into one of four categories: immunosuppression (reduction in efficacy or activation of immune system), immunostimulation (general enhanced immune response), 
hypersensitivity (specific immunostimulatory response mediated by immunoglobulins or T-cells), and autoimmunity (immune response against self). Immunotoxicity refers to any adverse effect on the structure or function of innate and adaptive immunity (see excellent references on this topic [15-18]).

Figure 1. Key considerations in biomarker development: identification, validation, and application.

\section{Key Considerations in Biomarker Development: Identification, Validation, and Application}
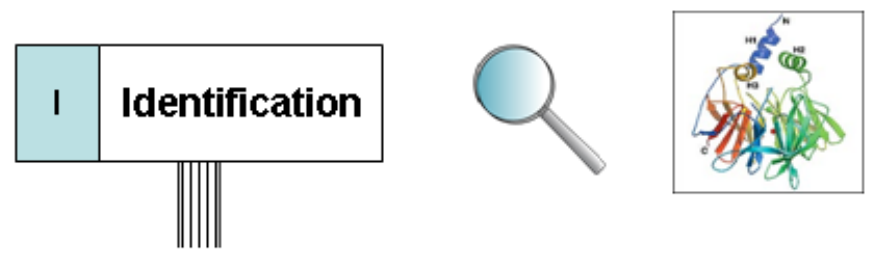

- Does pathological basis for disease suggest role for biomarker?

- Do animal or in vitro data support biomarker as mechanistically relevant?

- Is biomarker effect permanent, transient, or recoverable?

- Is biological sample required for biomarker measurement readily obtainable?
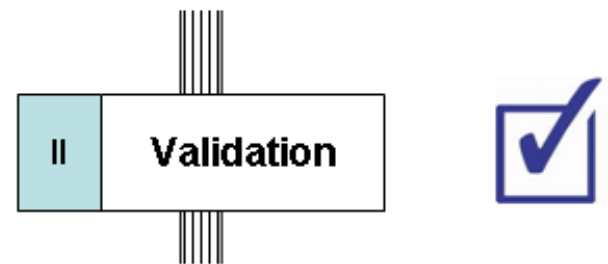

- Are the markers analytically detectable and reproducible?

-What is the assay technical variability?

-What is the human intra- and inter-individual variability?

- Is the marker affected by season or life-style factors?
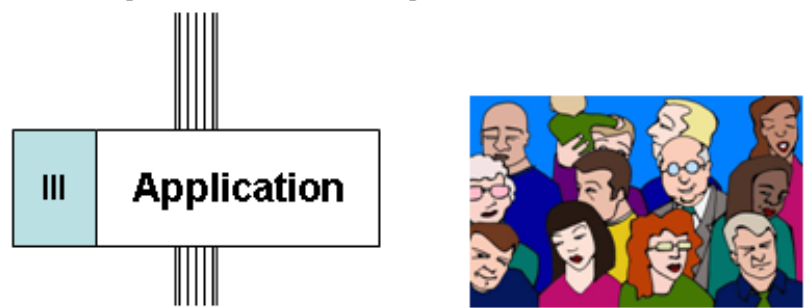

- Conduct additional proof-of-concept studies?

-What is the sample size needed to detect significant difference?

- Include additional biomarkers to confirm trends and associations?

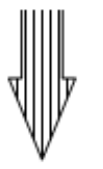

Biomarkers can be used for monitoring disease causality, progression, susceptibility, effects of environmental exposures and treatments in clinical trials

The most common immune markers and sample types are summarized in Table 1. For example, cell-surface markers and antibodies are commonly used to evaluate the status of the immune system and can be detected using whole blood or serum and plasma by a multitude of methods. Although 
blood collection is an invasive procedure, subjects are accustomed to blood draws. However, if the same biomarker can be detected in samples collected using a non-invasive procedure, such as saliva or urine, these could then be prioritized for development, particularly for studies intended for pediatric populations. Efforts to develop non-invasive collection methods include analysis of immune components in saliva $[19,20]$ or induced sputum [21] and exhaled breath condensate [22].

Table 1. Biomarkers used to investigate immunotoxicity in human studies.

\begin{tabular}{lll}
\hline Immune Markers & \multicolumn{1}{c}{ Examples of Endpoints } & \multicolumn{1}{c}{ Biological Samples } \\
\hline Cellular phenotype; & CD3, CD4, CD8, CD11c, CD19, CD25, & Whole blood, Urine \\
activation markers & CD56, CD14, basophils, neutrophils; & \\
& Activation markers: CD69, CD45RO, & \\
& CD45RA & \\
Antibodies & IgM, IgD, IgG, IgA, IgE, & Plasma, Breastmilk \\
Cytokines & IL-2, IL-4, IL-5, IL-10, IL-13, IFN- $\gamma$, & Serum/plasma, peripheral \\
& TNF- $\alpha$, GM-CSF & blood, urine, saliva \\
Chemokines & RANTES, IP-10, MIP-1 $\alpha$, MIP-1 $\beta$, & Serum/plasma \\
& MDC, TARC & \\
Proliferation Tests & Mitogenic stimulation (PHA, & Peripheral blood \\
& Concavalin A, specific antigen) & \\
\hline
\end{tabular}

\section{Sample Collection and Analytical Methods}

Biomarker studies require processing and storage of numerous biological samples with the goals of obtaining a large amount of information and minimizing future research costs. An efficient study design includes provisions for processing of the original samples, such as separation of various components (e.g., serum, plasma, clot etc.), stabilization, cryopreservation, DNA isolation, and preparation of specimens for exposure assessment [23]. Standard operating procedures and quality control plans help to protect sample quality and to assure validity of the biomarker data. Data validity can also be affected by the sample type used. For example, proteomic profiles reportedly differ between serum and plasma samples [24] with less reproducibility observed with serum samples [25-27]. Cytokine levels may be lower in serum than in stimulated whole blood cultures $[28,29]$. The types of blood collection tubes (proteins adsorb to different materials) or anti-coagulants used (heparin and EDTA have different mechanisms for the prevention of clotting) also contribute to variability in the data obtained [30]. Also, the effect of transportation and storage of biological material must be examined very closely as the assay can be time- and temperature-sensitive. These factors, in addition to the assay and method variables listed above, can affect the precision of the measurement. Any significant contributor can then be controlled for in the large-scale epidemiology studies.

Employment of high-throughput methods in large-scale epidemiology studies provide a number of advantages for study designs that involve the collection and timely analysis of numerous clinical samples. Flow cytometry has emerged as a powerful tool for quantitative, single-cell analysis of both surface markers and intracellular antigens. This platform can now be used to measure intracellular signaling cascades and phosphorylation events and are employed extensively in high-throughput drug screening. Multiplex detection of cytokines allows the simultaneous measurement of multiple 
cytokines in a sample [31]. These platforms increase the efficiency of measuring the cytokines while reducing the serum sample volumes required for the testing, thus replacing the more traditional ELISA-based approach. Compared to Cytokine Bead Array (CBA), Luminex kits were found to be highly reproducible and reliable [32]. Increased standardization between laboratories represents another challenge in the application of immune biomarkers. However, this is one that can be remedied with increased collaboration and exchange of information during which protocols and methods are shared across laboratories and the reproducibility of immune marker detection can be determined before the samples are analyzed. Variability in parameters measured by flow cytometry attributable to subjective gating and/or determination of positive versus negative events can be reduced by distributing templates for acquisition and data analysis among the sites involved in analysis [33].

\section{Case Studies: Asthma and Chronic Obstructive Pulmonary Disease (COPD)}

Application of these methods will be illustrated with examples from the field of asthma and chronic obstructive pulmonary disease (COPD), two of the most common disorders of the airways. In both cases, airway obstruction is the result of chronic inflammation and the infiltration of pro-inflammatory cells and mediators $[34,35]$. However, there are some noteworthy differences in the histopathology and the immune cells recruited for these two diseases [36]. The immune profiles of these diseases are summarized in Table 2 and, although there is a strong association between these immunologic endpoints and disease status, the predictive value of these endpoints are still under investigation.

Table 2. Findings from selected biomarker studies on the relationship between environmental exposures and health outcomes.

\begin{tabular}{|c|c|c|c|c|}
\hline & $\begin{array}{l}\text { Description of Epidemiology } \\
\text { Study Design \& Subjects }\end{array}$ & $\begin{array}{l}\text { Method of exposure } \\
\text { assessment }\end{array}$ & $\begin{array}{l}\text { Biological sample } \\
\text { and (immune } \\
\text { biomarkers employed) }\end{array}$ & $\begin{array}{l}\text { Key findings and evaluation } \\
\text { of concordance }\end{array}$ \\
\hline \multirow[t]{3}{*}{ Atopy } & $\begin{array}{l}\text { Longitudinal/Prospective; } \\
(\mathrm{n}=3,062) \text {, combined birth } \\
\text { cohorts (ages } 1-8 \text { years) }\end{array}$ & $\begin{array}{l}\text { Questionnaire; } \\
\text { indoor environment, } \\
\text { pet exposure }\end{array}$ & $\begin{array}{l}\text { Peripheral blood } \\
\text { (total and specific IgE } \\
\text { and CD14/IL13 } \\
\text { genotypes) }\end{array}$ & $\begin{array}{l}\text { Atopy influenced by IL13 in } \\
<8 \text { years and CD14 with pet } \\
\text { interaction in ages } 4 \text { and } 8 \\
\text { (Bottema et al. 2008) [37] }\end{array}$ \\
\hline & $\begin{array}{l}\text { Longitudinal; birth cohort } \\
(\mathrm{n}=172)\end{array}$ & & $\begin{array}{l}\text { Peripheral blood } \\
\text { (differential cell counts } \\
\text { and IFN- } \gamma, \text { TNF- } \alpha \text {, } \\
\text { IL-4, IL-5, IL-9, Il-10, } \\
\text { IL-13 by ELISA) }\end{array}$ & $\begin{array}{l}\text { Atopy associated with increased } \\
\text { Th2; bronchial hyperresponsiveness } \\
\text { associated with Th1 } \\
\text { (Heaton et al. 2005) [38] }\end{array}$ \\
\hline & $\begin{array}{l}\text { Cross-sectional; children } \\
\text { ages } 6-16(\mathrm{n}=24) \text { vs. } \\
\text { reference group }\end{array}$ & $\begin{array}{l}\text { Questionnaire; } \\
\text { parental tobacco } \\
\text { smoke }\end{array}$ & $\begin{array}{l}\text { Nasopharangeal } \\
\text { aspirate (analyzed for } \\
\text { IL-13 cytokine levels) }\end{array}$ & $\begin{array}{l}\text { ETS augments secretion of IL-13 } \\
\text { (Feleszko et al. 2006) [39] }\end{array}$ \\
\hline Asthma & $\begin{array}{l}\text { Longitudinal/Prospective; } \\
\text { birth cohort }(n=239)\end{array}$ & $\begin{array}{l}\text { Questionnaire; } \\
\text { pesticide and } \\
\text { allergen exposures }\end{array}$ & $\begin{array}{l}\text { Peripheral blood } \\
\text { (intracellular IFN- } \gamma \\
\text { and IL-4 in } \\
\text { T-helper cells) }\end{array}$ & $\begin{array}{l}\text { Th2 cells associated with asthma } \\
\text { and wheeze; Th1 associated with } \\
\text { breastfeeding and parental } \\
\text { occupation in agriculture } \\
\text { (Duramad et al. 2006) [40] }\end{array}$ \\
\hline
\end{tabular}


Table 2. Cont.

\begin{tabular}{|c|c|c|c|c|}
\hline & $\begin{array}{l}\text { Description of epidemiology } \\
\text { study design \& subjects }\end{array}$ & $\begin{array}{l}\text { Method of exposure } \\
\text { assessment }\end{array}$ & $\begin{array}{l}\text { Biological sample } \\
\text { and (immune } \\
\text { biomarkers employed) }\end{array}$ & $\begin{array}{l}\text { Key findings and evaluation } \\
\text { of concordance }\end{array}$ \\
\hline \multirow[b]{2}{*}{ Asthma } & $\begin{array}{l}\text { Cross-sectional; children } \\
\text { with asthma }(\mathrm{n}=33) \text { vs. } \\
\text { health controls }\end{array}$ & Questionnaire & $\begin{array}{l}\text { Exhaled breath } \\
\text { condensate (IFN- } \gamma \text {, } \\
\text { TNF- } \alpha, \text { IL-2, IL-4, } \\
\text { IL-5, IL-10) }\end{array}$ & $\begin{array}{l}\text { Cytokine levels low but } \\
\text { detectable; processing method } \\
\text { needs improvement } \\
\text { (Robroeks et al. 2006) [22] }\end{array}$ \\
\hline & $\begin{array}{l}\text { Case-control retrospective; } \\
\text { adults ages } 20-79 \\
(\mathrm{n}=3,443)\end{array}$ & $\begin{array}{l}\text { Questionnaire and } \\
\text { blood evaluation: } \\
\text { ethanol levels, } \\
\text { CDT1, GGT, } \\
\text { ASAT, ALAT }\end{array}$ & $\begin{array}{l}\text { Peripheral Blood; } \\
\text { (serum IgE) }\end{array}$ & $\begin{array}{l}\text { Positive associations between } \\
\text { alcohol consumption and } \\
\text { total IgE serum levels in } \\
\text { atopic subjects } \\
\text { (Friedrich } \text { et al. 2008) [41] }\end{array}$ \\
\hline \multirow{3}{*}{$\begin{array}{l}\text { Chronic } \\
\text { Obstructive } \\
\text { Pulmonary } \\
\text { Disease } \\
\text { (COPD) }\end{array}$} & $\begin{array}{l}\text { Cross-sectional; patients } \\
\text { with COPD }(\mathrm{n}=35) \\
\text { non-smokers }(\mathrm{n}=18) \\
\text { and smokers }(\mathrm{n}=20)\end{array}$ & $\begin{array}{l}\text { Questionnaire; } \\
\text { criteria for } \\
\text { non-smokers was } \\
\text { normal spirometry } \\
\text { results }\end{array}$ & $\begin{array}{l}\text { Induced sputum } \\
\text { (differential cell } \\
\text { counts; CXCL9, } \\
\text { CXCL10, CXCL11, } \\
\text { and CCL5 by ELISA) }\end{array}$ & $\begin{array}{l}\text { CXCR3 and CCL5 increased } \\
\text { in COPD patients compared } \\
\text { with non smokers } \\
\text { (Costa, et al. 2008) [42] }\end{array}$ \\
\hline & $\begin{array}{l}\text { Cross-sectional; patients } \\
\text { with COPD }(n=26) \\
\text { smokers }(n=19) \\
\text { healthy non-smokers }(n=5)\end{array}$ & $\begin{array}{l}\text { Questionnaire; } \\
\text { history of smoking }\end{array}$ & $\begin{array}{l}\text { Bronchial Alveolar } \\
\text { Lavage (BAL) and } \\
\text { peripheral blood (CD3, } \\
\text { CD4, CD8, CD45RA, } \\
\text { CD25, CD69) }\end{array}$ & $\begin{array}{l}\text { Increased CD8 and } \\
\text { CD4+CD25+ in COPD BAL } \\
\text { samples } \\
\text { (Smyth et al. 2007) [43] }\end{array}$ \\
\hline & $\begin{array}{l}\text { Cross-sectional; COPD } \\
(\mathrm{n}=30) \text {, divided into two } \\
\text { categories: Forced-expiratory } \\
\text { volume in } 1 \text { second (FEV1) } \\
<50 \% \text { and }>50 \%\end{array}$ & $\begin{array}{l}\text { Questionnaire; } \\
\text { smoking status }\end{array}$ & $\begin{array}{l}\text { Induced sputum } \\
\text { (IL-6, IL-8 and } \\
\text { TNF- } \alpha \text { ) }\end{array}$ & $\begin{array}{l}\text { Mean levels of three cytokines } \\
\text { elevated in severe vs. } \\
\text { moderate COPD } \\
\text { (Hacievliyagil et al. 2005) [44] }\end{array}$ \\
\hline
\end{tabular}

${ }^{1}$ carbohydrate-deficient transferring (CDT), gamma-glutamyl transferase (GGT), aspartate-amino transferase (ASAT), alanine-amino transferase (ALAT) are biomarkers of recent and long-term exposure to alcohol [45].

Bronchial biopsies from asthmatic patients reveal an infilitration of eosinophils, activated mucosal mast and $\mathrm{T}$ cells whereas in COPD eosinophils are largely absent but neutrophils are present in large numbers [46]. Also, in COPD, there is also an imbalance of the CD4+/CD8+ T-lymphocyte ratio in the lungs with CD8 predominating [43]. The inflammatory state of the lung is thought to be maintained through recruitment of macrophages and lymphocytes [34]. Increased expression of chemokine receptor CXCR3 on macrophages, and its ligand CXCL10 has been observed in patients with COPD [47]. In support of these findings, Costa et al. reported that in addition to CXCR3, chemokine receptors CXCL9, CXCL10, and CXCL11 were elevated in COPD, compared to non-smokers [42]. The levels of inflammatory cytokines (IL-6, IL-8, and TNF- $\alpha$ ) are also elevated in COPD [44]. The cumulative data available for this disease is in part due to the extensive validation efforts by researchers to standardize sample collection methods and biomarker endpoints analysis [48].

Asthma is characterized by chronic inflammation in the airways and the presence of a predominance of $\mathrm{CD}^{+}$T-helper 2 cells that secrete IL-4, IL-5, and IL-13 cytokines [49,50]. Th2 cells contribute to the immunopathogenesis of asthma by recruiting eosinophils and mast cells to the 
airways [51,52] and by inducing B-cells to produce immunoglobulin E antibodies [53]. Increased levels of IFN- $\gamma$ also have been reported in cases of severe asthma that could involve $\mathrm{CD} 8^{+} \mathrm{T}$ cells [54]. In childhood, a major risk factor for the development of persistent asthma is atopy, which is defined by the presence of IgE to common inhalant allergens such as house dust mite [55]. Polymorphisms in CD14, a membrane receptor for bacterial components, have been linked to atopy [56]. In a comprehensive study by Heaton et al. [38], multiple immune markers were used to differentiate between various airway disease phenotypes in children. The authors reported that atopic children were more likely to have increased T-helper 2 (Th2) cytokines such as interleukin IL-4, IL-5, IL-13 whereas children with bronchial hyper-reactivity were more likely to have elevated IFN- $\gamma$, a Th1 cytokine [38]. The associations of Th1/Th2 are not consistent for all allergic disorders. For example, Kaneko et al. [57] reports that atopic dermatitis (AD) is associated with increased IL-4 Th2 cells, whereas Machura et al. [58] report that children with AD have significantly lower IL-4 Th2 cells and TNF- $\alpha$ Th1 cells and, therefore, no distinct bias towards Th1 or Th2 profiles.

Hollams et al. (2009) [59] sought to identify biomarkers associated with asthma phenotypes in teenagers, particularly atopic asthma, and to identify markers that aid in discriminating between atopic subjects at high versus low risk of asthma. In a cohort of 1380 14-year olds, clinical history as well as measurement of circulating and/or inflammatory markers (e.g., eosinophils, IgE, cytokine measurements) and in vitro innate and adaptive immune functions (e.g., house dust mite (HDM) T-cell responses) were evaluated. HDM-induced cytokine expression of IL-5, IL-9, IL-10, IL-13, and IFN- $\gamma$ were significantly elevated in teens with asthma. Due to the redundancy of the immune system, for example IL-5, IL-9 and IL-13 contribute to the Th2 response and generation of IgE, therefore it is important to examine changes in several cytokines simultaneously rather than in isolation.

\section{Emerging Methods}

Advances in technology have introduced a variety of "omic" approaches to study human diseases and identify new biomarkers [60]. Interrogation of DNA (genomics) reflects genetic variability, mRNA (also genomics, sometimes called transcriptomics) displays changes in gene expression, proteins (proteomics) represent cellular and enzymatic changes (proteomics), and metabolites (metabonomics) highlight the physiological endpoints [9]. Toxicogenomics, the identification of specific gene expression profiles in biological systems associated with xenobiotic exposure, is increasingly being applied in immunotoxicity assessments [61]. For example, children with the TGF- $\beta 1$-509TT genotype are at increased risk of asthma when they are exposed to maternal smoking in utero or to traffic-related emissions [62]. In immunotoxicology studies, microarrays have been used mainly in drug development to model pharmacodynamic effects of pharmaceuticals [63]. Multiparameter flow cytometry can also provide insight into cell maintenance and function; these include immunophenotyping, cell cycle and proliferation markers, indicators of cell injury and death, intracellular functional and biochemical analyses [64].

Immunomics involves the integration of the immune-related genomics and proteomics; this approach will help in the synthesis of vast, and sometimes redundant, information. It is of particular relevance to the field of environmental health research in which biological data is collected from subjects to evaluate the associations between environmental exposures (e.g., xenobiotics, allergens) 
and disease outcomes (e.g., asthma, COPD). For example, single nucleotide polymorphisms (SNPs) in immune-related genes suspected to be involved in disease pathology can be evaluated together with the protein expression of that gene. As it is unlikely that a complete data set of cytokines, for example, can be gathered from one study, inputing the limited data set into an interactive map of the cytokine pathway could prove useful for interpreting the net immune response. This would be particularly useful in instances where there is redundancy or overlap in the functions of cytokines and/or immune cells. Diaz-Ramos et al. (2010) [65] recently described the development of a comprehensive immunome that identified 1,015 genes expressed in immune cells or lymphoid tissues that correspond to proteins located on the plasma membrane. The identification of an immunomic profile will contribute to the compilation of "fingerprints" of dysregulated immunity; these will prove useful in the investigation of environmental health diseases and the process of linking environmental exposures to immune disorders.

\section{Discussion and Conclusions}

Immunoinformatics, including the software and hardware capable of synthesizing this information will enable researchers to visualize global changes in protein expression profiles relevant markers of interest [66-68]. Research areas of immunoinformatics include (1) allergy prediction, (2) understanding of immune-related genes, (3) study of genes and their expressions in healthy and diseased states, (4) T- and B- cell epitope prediction, and in silico vaccination [66]. Yan (2010) [69] has summarized the resources available on the genetic variation on the immune system. Integration of accumulating data will be an important step in identifying a useful immunologic marker. This can be accomplished by an integrated evaluation of multiple data sets obtained (biological, epidemiological, statistical, clinical trial) and evaluating the risk-benefit evidence. [70]. For example, the use of a scale to rate the level of evidence provided (study design, target outcome, and statistical evaluation), with level 1 the strongest evidence and 5 the weakest; 2 represents a potential surrogate marker. The criteria listed in this rating system were used to evaluate biomarkers for the immune disorder rheumatoid arthritis and the marker CD68, specific for macrophages, was designated a level three (epidemiology studies were not considered to be statistically powered), whereas the soluble marker C-reactive protein was deemed difficult to rank [71]. Weak clinical study design, including power and duration, was cited as the main limitation of this study [72]. Several factors that contribute to the variability of immune parameters are host factors and assay variation, and both of these can be addressed when designing the study. Host factors (e.g., sex, age, ethnicity/geography, nutrition) [73] and exposure factors (e.g., chemicals, bioaerosols, season, smoking, alcohol etc.) and disease states (e.g. leukemia, asthma, infections, etc.) also contribute to the variability of immune biomarkers [74,75]. For example, when lymphocyte subsets were analyzed in children who ranged in age from newborns to 18 years old, age was found to be an important factor in distributions of cell types [76]. Stress [77] and socioeconomic status [78] also impact the status of asthma in children and adolescents, identified by changes in cytokine biomarkers (IL-4, IL-5, and IFN- $\gamma$ ). In adults, alcohol intake has been associated with increased serum IgE levels [41]. The intra-individual variability should be low, compared to the inter-individual variability. Additionally, the effect of other host factors such as age, gender, stress, 
exercise, and smoking on biomarker measurement should also be well-characterized. The markers should be analytically detectable and reproducible in the same laboratory and in others.

In conclusion, the use of immune biomarkers in human clinical trials and molecular epidemiology of environmental health can facilitate a better understanding of the mechanisms that underlie associations between environmental exposures and immune-mediated disorders, such as cancer, asthma, and autoimmune disorders. An integrated approach that incorporates host and environmental factors will be particularly important in the development and application of immunologic biomarkers in public health research.

\section{References}

1. Finn, O.J. Cancer immunology. N. Engl. J. Med. 2008, 358, 2704-2715.

2. Hansson, G.K.; Nilsson, J. Introduction: Atherosclerosis as inflammation: A controversial concept becomes accepted. J. Intern. Med. 2008, 263, 462-463.

3. Libby, P. The molecular mechanisms of the thrombotic complications of atherosclerosis. J. Intern. Med. 2008, 263, 517-527.

4. Chou, M.Y.; Hartvigsen, K.; Hansen, L.F.; Fogelstrand, L.; Shaw, P.X.; Boullier, A.; Binder, C.J.; Witztum, J.L. Oxidation-specific epitopes are important targets of innate immunity. J. Intern. Med. 2008, 263, 479-488.

5. Biomarkers Definitions Working Group; Atkinson, A.J.; Colburn, W.A.; DeGruttola, V.G.; DeMets, D.L.; Downing, G.J.; Hoth, D.F.; Oates, J.A.; Peck, C.C.; Schooley, R.T.; Spilker, B.A.; Woodcock, J.; Zeger, S.L. Biomarkers and surrogate endpoints: Preferred definitions and conceptual framework. Clin. Pharm. Ther. 2001, 69, 89-95.

6. Altar, C.A. The biomarkers consortium: On the critical path of drug discovery. Clin. Pharm. Ther. 2008, 83, 361-364.

7. Swenberg, J.A.; Fryar-Tita, E.; Jeong, Y.C.; Boysen, G.; Starr, T.; Walker, V.E.; Albertini, R.J. Biomarkers in toxicology and risk assessment: Informing critical dose-response relationships. Chem. Res. Toxicol. 2008, 21, 253-265.

8. Baker, M. In biomarkers we trust? Nat. Biotechnol. 2005, 23, 297-304.

9. Dieterle, F.; Marrer, E. New technologies around biomarkers and their interplay with drug development. Anal. Bioanal. Chem. 2008, 390, 141-154.

10. Banerji, U.; de Bono, J.; Judson, I.; Kaye, S. Biomarkers in early clinical trials: The committed and the skeptics. Clin. Cancer Res. 2008, 14, 2512:3-2512:4.

11. Bohler, T.; Nolting, J.; Kamar, N.; Gurragchaa, P.; Reisener, K.; Glander, P.; Neumayer, H.-H.; Budde, K.; Klupp, J. Validation of immunological biomarkers for the pharmacodynamic monitoring of immunosuppressive drugs in humans. Ther. Drug Monit. 2007, 29, 77-86.

12. Metcalf, S.W.; Orloff, K.G. Biomarkers of exposure in community settings. J. Toxicol. Environ. Health 2004, 67, 715-726.

13. Lesko, L.J.; Atkinson, A.J., Jr. Use of biomarkers and surrogate endpoints in drug development and regulatory decision making: Criteria, validation, strategies. Annu. Rev. Pharmacol. Toxicol. 2001, 41, 347-366. 
14. Buyse, M.; Molenberghs, G.; Burzykowski, T.; Renard, D.; Geys, H. The validation of surrogate endpoints in meta-analyses of randomized experiments. Biostatistics 2000, 1, 49-67.

15. Immunotoxicology and Immunopharmacology, 3rd ed.; Luebke, R.W., House, R., Kimber, I., Eds.; CRC Press: Boca Raton, FL, USA, 2007.

16. De Jong, W.H.; Van Loveren, H. Screening of xenobiotics for direct immunotoxicity in an animal study. Methods 2007, 41, 3-8.

17. Descotes, J. Methods of evaluating immunotoxicity. Expert Opin. Drug Metab. Toxicol. 2006, 2, 249-259.

18. Descotes, J.; Testud, F. Toxicovigilance: A new approach for the hazard identification and risk assessment of toxicants in human beings. Toxicol. Appl. Pharmacol. 2005, 207, 599-603.

19. Winkler, O.; Hadnagy, W.; Idel, H. Cytokines detectable in saliva of children as appropriate markers of local immunity of the oral cavity-An approach for the use in air pollution studies. Int. J. Hyg. Environ. Health 2001, 204, 181-184.

20. Soo-Quee Koh, D.; Choon-Huat Koh, G. The use of salivary biomarkers in occupational and environmental medicine. Occup. Environ. Med. 2007, 64, 202-210.

21. Simpson, J.L.; Wood, L.G.; Gibson, P.G. Inflammatory mediators in exhaled breath, induced sputum and saliva. Clin. Exp. Allergy 2005, 35, 1180-1185.

22. Robroeks, C.M.; Jobsis, Q.; Damoiseaux, J.G.; Heijmans, P.; Rosias, P.; Hendriks, H.; Dompeling, E. Cytokines in exhaled breath condensate of children with asthma and cystic fibrosis. Ann. Allergy Asthma Immunol. 2006, 96, 349-355.

23. Holland, N.T.; Pfleger, L.; Berger, E.; Ho, A.; Bastaki, M. Molecular epidemiology biomarkers-Sample collection and processing considerations. Toxicol. Appl. Pharmacol. 2005, 206, 261-268.

24. Hsieh, S.Y.; Chen, R.K.; Pan, Y.H.; Lee, H.L. Systematical evaluation of the effects of sample collection procedures on low-molecular-weight serum/plasma proteome profiling. Proteomics 2006, 6, 3189-3198.

25. Baggerly, K.A.; Morris, J.S.; Coombes, K.R. Reproducibility of SELDI-TOF protein patterns in serum: Comparing datasets from different experiments. Bioinformatics 2004, 20, 777-785.

26. Diamandis, E.P. Point: Proteomic patterns in biological fluids: Do they represent the future of cancer diagnostics? Clin. Chem. 2003, 49, 1272-1275.

27. Diamandis, E.P. Analysis of serum proteomic patterns for early cancer diagnosis: Drawing attention to potential problems. J. Nat. Cancer Inst. 2004, 96, 353-356.

28. Jason, J.; Larned, J. Single-cell cytokine profiles in normal humans: Comparison of flow cytometric reagents and stimulation protocols. J. Immunol. Method. 1997, 207, 13-22.

29. Duramad, P.; McMahon, C.W.; Hubbard, A.; Eskenazi, B.; Holland, N.T. Flow cytometric detection of intracellular TH1/TH2 cytokines using whole blood: Validation of immunologic biomarker for use in epidemiologic studies. Cancer Epidemiol. Biomarkers Prev. 2004, 13, 1452-1458.

30. Luque-Garcia, J.L.; Neubert, T.A. Sample preparation for serum/plasma profiling and biomarker identification by mass spectrometry. J. Chromatogr. 2007, 1153, 259-276. 
31. Richens. J.L.; Urbanowicz, R.A.; Metcalf, R.; Corne, J.; O’Shea, P.; Fairclough, L. Quantitative validation and comparison of multiplex cytokine kits. J. Biomol. Screen. 2010, 15, 562-568.

32. Lash, G.E.; Pinto, L.A. Multiplex cytokine analysis technologies. Expert Rev. Vaccines 2010, 9, 1231-1237.

33. Maecker, H.T.; McCoy, J.P., Jr.; Amos, M.; Elliott, J.; Gaigalas, A.; Wang, L.; Aranda, R.; Banchereau, J.; Boshoff, C.; Braun, J.; et al. A model for harmonizing flow cytometry in clinical trials. Nat. Immunol. 2010, 11, 975-978.

34. Cosio, M.G.; Majo, J.; Cosio, M.G. Inflammation of the airways and lung parenchyma in COPD: Role of T cells. Chest 2002, 121, 160S-165S.

35. Hogg, J.C. Infection and COPD. Exp. Lung Res. 2005, 31, 72-73.

36. Baraldo, S.; Lokar, O.K.; Turato, G.; Zuin, R.; Saetta, M. The role of lymphocytes in the pathogenesis of asthma and COPD. Curr. Med. Chem. 2007, 14, 2250-2256.

37. Bottema, R.W.; Reijmerink, N.E.; Kerkhof, M.; Koppelman, G.H.; Stelma, F.F.; Gerritsen, J.; Thijs, C.; Brunekreef, B.; van Schayck, C.P.; Postma, D.S. IL13, CD14, pet and tobacco smoke influence atopy in 3 Dutch cohorts: The allergenic study. Eur. Resp. J. 2008, 32, 593-602.

38. Heaton, T.; Rowe, J.; Turner, S.; Aalberse, R.C.; de Klerk, N.; Suriyaarachchi, D.; Serralha, M.; Holt, B.J.; Hollams, E.; Yerkovich, S.; et al. An immunoepidemiological approach to asthma: Identification of in vitro T-cell response patterns associated with different wheezing phenotypes in children. Lancet 2005, 365, 142-149.

39. Feleszko, W.; Zawadzka-Krajewska, A.; Matysiak, K.; Lewandowska, D.; Peradzyńska, J.; Dinh, Q.T.; Hamelmann, E.; Groneberg, D.A.; Kulus, M. Parental tobacco smoking is associated with augmented IL-13 secretion in children with allergic asthma. J. Allerg. Clin. Immunol. 2006, 117, 97-102.

40. Duramad, P.; Harley, K.; Lipsett, M.; Bradman, A.; Eskenazi, B.; Holland, N.T.; Tager, I.B. |Early environmental exposures and intracellular Th1/Th2 cytokine profiles in 24-month-old children living in an agricultural area. Environ. Health Perspect. 2006, 114, 1916-1922.

41. Friedrich, N.; Husemoen, L.L.; Petersmann, A.; Nauck, M.; Völzke, H.; Linneberg, A. The association between alcohol consumption and biomarkers of alcohol exposure with total serum immunoglobulin E levels. Alcohol. Clin. Exp. Res. 2008, 32, 983-990.

42. Costa, C.; Rufino, R.; Traves, S.L.; Silva, J.R.L.; Barnes, P.J.; Donnelly, L.E. CXCR3 and CCR5 chemokines in induced sputum from patients with COPD. Chest 2008, 133, 26-33.

43. Smyth, L.J.; Starkey, C.; Vestbo, J.; Singh, D. CD4-regulatory cells in COPD patients. Chest 2007, 132, 156-163.

44. Hacievliyagil, S.S.; Gunen, H.; Mutlu, L.C.; Karabulut, A.B.; Temel, İ. Association between cytokines in induced sputum and severity of chronic obstructive pulmonary disease. Res. Med. 2006, 100, 846-854.

45. Niemela, O. Biomarkers in alcoholism. Clin. Chim. Acta 2007, 377, 39-49.

46. Barnes, P.J. Immunology of asthma and chronic obstructive pulmonary disease. Nat. Rev. 2008, 8, 183-192. 
47. Saetta, M.; Mariani, M.; Panina-Bordignon, P.; Turato, G.; Buonsanti, C.; Baraldo, S.; Bellettato, C.M.; Papi, A.; Corbetta, L.; Zuin, R.; et al. Increased expression of the chemokine receptor CXCR3 and its ligand CXCL10 in peripheral airways of smokers with chronic obstructive pulmonary disease. Amer. J. Respir. Crit. Care Med. 2002, 165, 1404-1409.

48. Snell, N.; Newbold, P. The clinical utility of biomarkers in asthma and COPD. Curr. Opin. Pharmacol. 2008, 8, 222-235.

49. Chung, K.F.; Barnes, P.J. Cytokines in asthma. Thorax 1999, 54, 825-857.

50. Ngoc, P.L.; Gold, D.R.; Tzianabos, A.O.; Weiss, S.T.; Celedón, J.C. Cytokines, allergy, and asthma. Curr. Opin. Allergy Clin. Immunol. 2005, 5, 161-166.

51. Macfarlane, A.J.; Kon, O.M.; Smith, S.J.; Zeibecoglou, K.; Khan, L.N.; Barata, L.T.; McEuen, A.R.; Buckley, M.G.; Walls, A.F.; Meng, Q.; et al. Basophils, eosinophils, and mast cells in atopic and nonatopic asthma and in late-phase allergic reactions in the lung and skin. J. Allerg. Clin. Immunol. 2000, 105, 99-107.

52. Marone, G.; Triggiani, M.; de Paulis, A. Mast cells and basophils: Friends as well as foes in bronchial asthma? Trends Immunol. 2005, 26, 25-31.

53. Yssel, H.; Abbal, C.; Pene, J.; Bousquet, J. The role of IgE in asthma. Clin. Exp. Allergy 1998, 28 (Suppl. 5), 104-109.

54. Brown, V.; Warke, T.J.; Shields, M.D.; Ennis, M. T cell cytokine profiles in childhood asthma. Thorax 2003, 58, 311-316.

55. Yeatts, K.; Sly, P.; Shore, S.; Weiss, S.; Martinez, F.; Geller, A.; Bromberg, P.; Enright, P.; Koren, H.; Weissman, D.; Selgrade, M.J. A brief targeted review of susceptibility factors, environmental exposures, asthma incidence, and recommendations for future asthma incidence research. Environ. Health Perspect. 2006, 114, 634-640.

56. Baldini, M.; Lohman, I.C.; Halonen, M.; Erickson, R.P.; HoltM P.G.; Martinez, F.D. A Polymorphism* in the 5' flanking region of the CD14 gene is associated with circulating soluble CD14 levels and with total serum immunoglobulin E. Am. J. Respir. Cell Mol. Biol. 1999, 20, 976-983.

57. Kaneko, H.; Matsui, E.; Asano, T.; Kato, Z.; Teramoto, T.; Aoki, M.; Kawamoto, N.; Lian, L.A.; Kasahara, K.; Kondo, N. Suppression of IFN-gamma production in atopic group at the acute phase of RSV infection. Pediatr. Allergy Immunol. 2006, 17, 370-375.

58. Machura, E.; Mazur, B.; Kwiecien, J.; Karczewska, K. Intracellular production of IL-2, IL-4, IFN-gamma, and TNF-alpha by peripheral blood CD3+ and CD4+ T cells in children with atopic dermatitis. Eur. J. Pediatr. 2007, 166, 789-795.

59. Hollams, E.M.; Deverell, M.; Serralha, M.; Suriyaarachchi, D.; Parsons, F.; Zhang, G.; de Klerk, N.; Holt, B.J.; Ladyman, C.; Sadowska, A.; et al. Elucidation of asthma phenotypes in atopic teenagers through parallel immunophenotypic and clinical profiling. J. Allerg. Clin. Immunol. 2009, 124, 463-470.

60. Benninghoff, A.D. Toxicoproteomics - The next step in the evolution of environmental biomarkers. Toxicol. Sci. 2007, 95, 1-4. 
61. Baken, K.A.; Vandebriel, R.J.; Pennings, J.L.; Kleinjansa, J.C.; van Loveren, H. Toxicogenomics in the assessment of immunotoxicity. Methods 2007, 41, 132-141.

62. Salam, M.T.; Gauderman, W.J.; McConnell, R.; Lin, P.-C.; Gilliland, F.D. Transforming growth factor- $\beta 1$ C-509T polymorphism, oxidant stress, and early-onset childhood asthma. Amer. J. Respir. Crit. Care Med. 2007, 176, 1192-1199.

63. Pruett, S.B.; Holladay, S.D.; Prater, M.R.; Yucesoy, B.; Luster, M.I. The promise of genomics and proteomics in immunotoxicology and immunopharmacology. In Immunotoxicology and Immunopharmacology, 3rd ed; Luebke, R.W., House, R., Kimber, I., Eds.; CRC Press: Boca Raton, FL, USA, 2007; pp. 79-95.

64. Burns-Naas, L.A.; Kerkvliet, N.I.; Laskin, D.L.; Bortner, C.D.; Burchiel, S.W. The use of multiparameter flow cytometry in immunotoxicology and immunopharmacology. In Immunotoxicology and Immunopharmacology, 3rd ed.; Luebke, R.W., House, R., Kimber, I., Eds.; CRC Press: Boca Raton, FL, USA, 2007; pp. 97-122.

65. Diaz-Ramos, M.C.; Engel, P.; Bastos, R. Towards a comprehensive human cell-surface immunome database. Immunol. Lett. 2010, 134, 183-187.

66. Tomar, N.; De, R.K. Immunoinformatics: An integrated scenario. Immunology 2010, 131, 153-168.

67. Korber, B.; LaBute, M.; Yusim, K. Immunoinformatics comes of age. PLoS Comput. Biol. 2006, 2, e71:0484-e71:0494.

68. Tong, J.C.; Ren, E.C. Immunoinformatics: Current trends and future directions. Drug Discov. Today 2009, 14, 684-689.

69. Yan, Q. Immunoinformatics and systems biology methods for personalized medicine. Meth. Mol. B 2010, 662, 203-220.

70. Lassere, M.N. The biomarker-surrogacy evaluation schema: A review of the biomarker-surrogate literature and a proposal for a criterion-based, quantitative, multidimensional hierarchical levels of evidence schema for evaluating the status of biomarkers as surrogate endpoints. Stat. Methods Med. Res. 2008, 17, 303-340.

71. Maksymowych, W.P.; Landewe, R.; Boers, M.; Garnero, P.; Geusens, P.; El-Gabalawy, H.; Heinegard, D.; Kraus, V.B.; Krause, V.; Lohmander, S.; et al. Development of draft validation criteria for a soluble biomarker to be regarded as a valid biomarker reflecting structural damage endpoints in rheumatoid arthritis and spondyloarthritis clinical trials. J. Rheumatol. 2007, 34, 634-640.

72. Lassere, M.N.; Johnson, K.R.; Boers, M.; Tugwell, P.; Brooks, P.; Simon, L.; Strand, V.; Conaghan, P.G.; Ostergaard, M.; Maksymowych, W.P.; et al. Definitions and validation criteria for biomarkers and surrogate endpoints: Development and testing of a quantitative hierarchical levels of evidence schema. J. Rheumatol. 2007, 34, 607-615.

73. Kant, A.K.; Graubard, B.I. Ethnic and socioeconomic differences in variability in nutritional biomarkers. Amer. J. Clin. Nutr. 2008, 87, 1464-1471.

74. Duramad, P.; Tager, I.B.; Holland, N.T. Cytokines and other immunological biomarkers in children's environmental health studies. Toxicol. lett. 2007, 172, 48-59.

75. Colosio, C.; Birindelli, S.; Corsini, E.; Galli, C.L.; Maroni, M. Low level exposure to chemicals and immune system. Toxicol. Appl. Pharmacol. 2005, 207, 320-328. 
76. Shearer, W.T.; Rosenblatt, H.M.; Gelman, R.S.; Oyomopito, R.; Plaeger, S.; Stiehm, E.R.; Wara, D.W.; Douglas, S.D.; Luzuriaga, K.; McFarland, E.J.; et al. Lymphocyte subsets in healthy children from birth through 18 years of age: The pediatric AIDS clinical trials group P1009 study. J. Allerg. Clin. Immunol. 2003, 112, 973-980.

77. Wolf, J.M.; Nicholls, E.; Chen, E. Chronic stress, salivary cortisol, and alpha-amylase in children with asthma and healthy children. Biol. Psychol. 2008, 78, 20-28.

78. Chen, E.; Fisher, E.B.; Bacharier, L.B.; Strunk, R.C. Socioeconomic status, stress, and immune markers in adolescents with asthma. Psychosom. Med. 2003, 65, 984-992.

(C) 2011 by the authors; licensee MDPI, Basel, Switzerland. This article is an open access article distributed under the terms and conditions of the Creative Commons Attribution license (http://creativecommons.org/licenses/by/3.0/). 